\title{
Kinetic modelling and determination of octylphenol ethoxylate (OPE) and bisphenol A (BPA) (used as plastic additives) inhibition constants for nitrogen conversion
}

\section{Dinçer A.R.*}

Department of Environmental Engineering, Çorlu Faculty of Engineering, Tekirdağ Namık Kemal University, Tekirdağ, Turkey Received: 09/03/2021, Accepted: 20/05/2021, Available online: 26/05/2021

*to whom all correspondence should be addressed: e-mail: adincer@nku.edu.tr https://doi.org/10.30955/gnj.003591

\section{Graphical abstract}

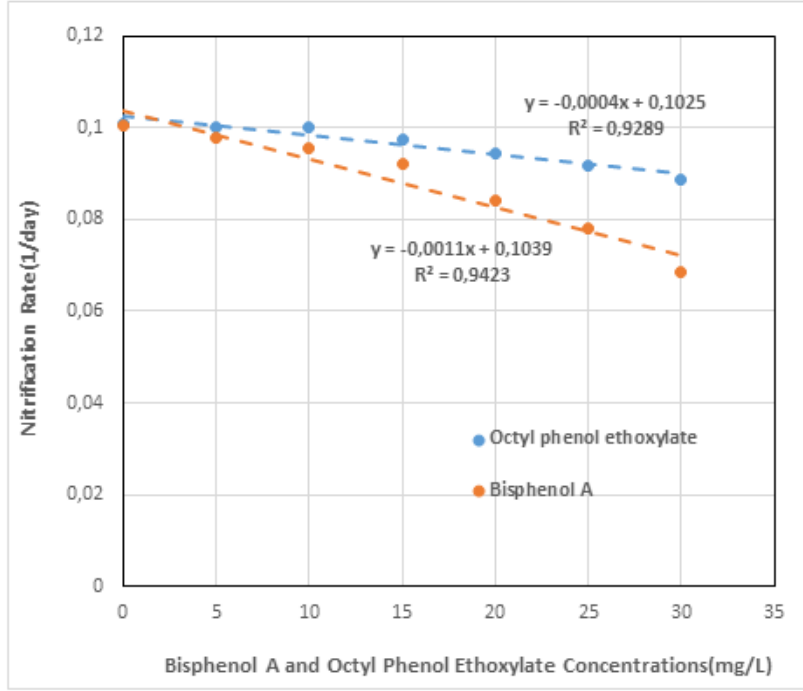

\begin{abstract}
Conversion of ammonia to nitrate is sensitive to a number of inhibitors. There is limited information on the nitrification inhibition coefficient and kinetic model in the current literature. Octyl Phenol Ethoxylate (OPE) and Bisphenol A (BPA) inhibition constants were found in nitrogen removal using an activated sludge system. Firstly, OPE- and BPA-free wastewater was used to determine the optimum operating conditions. The effect of OPE and BPA concentration on system performance was investigated. The ammonium removal rate was less affected by lower OPE and BPA concentrations. When the BPA and OPE concentrations were increased from $0 \mathrm{mg} / \mathrm{L}$ to $30 \mathrm{mg} / \mathrm{L}$, the effluent ammonium nitrogen concentrations were increased respectively from $2.8 \mathrm{mg} / \mathrm{L}$ to $49.8 \mathrm{mg} / \mathrm{L}$ and from $2.6 \mathrm{mg} / \mathrm{L}$ to $20.40 \mathrm{mg} / \mathrm{L}$. Due to the inhibition created by these compounds on Nitrobacter, nitrite nitrogen increased in the medium. As the OPE and BPA concentrations increased, the conversion rate of the ammonium nitrogen into nitrate decreased. Based on the
\end{abstract}

experimental results, a kinetic model was developed, and the OPE and BPA inhibition constants ( $K_{O P E}$ and $\mathrm{K}_{\mathrm{BPA}}$ ) were found to be $207.8 \mathrm{mg} / \mathrm{L}$ and $63.58 \mathrm{mg} / \mathrm{L}$, respectively. In nitrogen removal, BPA created a higher inhibition effect in comparison to OPE.

Keywords: Bisphenol A, octylphenol ethoxylate, nitrification kinetics, inhibition.

\section{Introduction}

Nitrification and denitrification processes are widely used in nitrogen removal from wastewater. Nitrification involves conversion of nitrogenous compounds to nitrite and nitrate by Nitrosomonas and Nitrobacter, respectively (Aslan et al., 2017; Randall et al., 1984; Yeung et al., 2013). Biological nitrification is a method known to reduce high ammonium concentrations in wastewater to acceptable levels in receiving environments. The kinetics and performance of a nitrification system depend on the slow growth rate of nitrilators and their sensitivity to metallic toxic substances. Since nitrification bacteria are sensitive to chemicals, these bacteria are considered as possible biological analysis organisms in evaluation of toxicity levels (Lee et al., 1997). As nitrification bacteria grow slowly and are sensitive to physical, chemical and environmental conditions, this may lead to nitrification instability in purification systems (Yeung et al., 2013). Heavy metals have a toxic effect on bacteria at certain concentrations, and they have a negative impact on biological treatment efficiency (Bhat et al., 2020). Discharge of industrial and urban wastewaters containing endocrine disrupting compounds to receiving environments is a significant cause of pollution (Auriol et al., 2006; Ying et al., 2009).

Endocrine disrupting compounds, such as Octyl Phenol Ethoxylate (OPE), are chemicals that act as hormones, creating negative effects on living things (Cirja et al., 2008; Dinçer et al., 1999; Llorca et al., 2017). Effective treatment of endocrine disrupting compounds with this complex structure is an important issue. Extensive studies are available to completely treat endocrine disrupting compounds, turn them into harmless products or remove their endocrine activities. In recent years, the discovery of 
the estrogen-like activity of the metabolites of some alkylphenols and APEOs, including 4-nonylphenol and 4tert octyl phenol, has caused concern about endocrine disrupting effects observed in aquatic biota (Bolong et al., 2009; Peng et al., 2015). Due to the hydrophobic and nonionic structures of these compounds, their biological treatment is poor, and the remaining products may have toxic effects in receiving environments (Ferguson et al., 2000; Nimrod et al., 1996). Due to their high consumption rates, Bisphenol A (BPA) and Octyl Phenol Ethoxylate (OPE) have recently been known as two xenobiotics that have attracted academic interest. BPA and OPE have been reported to be common everywhere in the environment (Umar et al., 2013). As BPA is stable and accumulated in the environment, to remove BPA from a receiving water body, it is needed to apply an effective treatment method (Hu et al., 2018).

BPA is used prevalently in the production of plastics and some resins. It is also used as a stabilizer and antioxidant in plastic production (Deborde et al., 2008). Current studies have shown that the concentrations of nonylphenol and octyl phenol in most rivers range from 0.007 to $32.8 \mathrm{ug} / \mathrm{L}$ and 0.0008 to $1.44 \mathrm{ug} / \mathrm{L}$, respectively. BPA concentrations of $0.026-8.4 \mathrm{mg} / \mathrm{L}$ were measured in receiving environments (Sharma et al., 2009; Urase et al., 2003). BPA concentrations up to $12.3 \mu \mathrm{g} / \mathrm{L}$ were measured from seepage waters originating from sanitary landfills (Deborde et al., 2008). High concentrations of BPA as $17.2 \mathrm{mg} / \mathrm{L}$ were measured in solid waste landfill seepage waters. It was reported that the main sources of BPA are plastic wastes among solid wastes (Yamamoto et al., 2001). By using membrane reactors, it is possible to remove $85-96 \%$ of endocrine disrupting substances from the environment (Spring et al., 2007). In a study that was conducted by using an activated sludge system to remove endocrine disrupting compounds, a BPA removal rate of higher than $70 \%$ was achieved (Lee et al., 2008). In a study conducted by Dinçer et al. using biofilters, it was found that OPE and BPA had an inhibition effect on bacteria (Dinçer et al., 2018).

In this study, the inhibition constants of OPE and BPA were found on nitrification bacteria, and a kinetic model was developed.

\section{Material and methods}

\subsection{Experimental setup}

A laboratory-scale experimental setup was used as shown in Figure 1. The volumes in the aeration and settling tanks were $8.0 \mathrm{~L}$ and $3.0 \mathrm{~L}$, respectively. The sedimentation tank was separated from the aeration tank. The reactor was continuously aerated, and the dissolved oxygen concentration was kept above $4.0 \mathrm{mg} / \mathrm{L}$. The temperature in the reactor was $25 \pm 1{ }^{\circ} \mathrm{C}$.

\subsection{Medium}

The synthetic wastewater was composed of $150 \mathrm{mg} / \mathrm{L} \mathrm{NH}_{4}$ $\mathrm{N}, 800 \mathrm{mg} / \mathrm{L}$ alkalinity $\left(\mathrm{CaCO}_{3}\right)$ and $45 \mathrm{mg} / \mathrm{L} \mathrm{KH}_{2} \mathrm{PO}_{4} .0 .5$ molar $\mathrm{NaHCO}_{3}$ was automatically added to the aeration tank to keep the reactor $\mathrm{pH}$ at $7.5 \pm 0.5$. The BPA and OPE concentrations varied between 5 and $30 \mathrm{mg} / \mathrm{L}$. The required amounts of BPA and OPE were weighed on a precision scale and dissolved in distilled water for one day by mixing. The obtained solution was transferred to the feeding tank and used in the experiments. The influent wastewater was prepared synthetically with distilled water. The micronutrients included: $50 \mathrm{mg} / \mathrm{L} \mathrm{MgSO}_{4} .7 \mathrm{H}_{2} \mathrm{O}$, $5 \mathrm{mg} / \mathrm{L} \mathrm{MnSO}_{4} . \mathrm{H}_{2} \mathrm{O}, 10 \mathrm{mg} / \mathrm{L} \mathrm{FeSO}_{4} .7 \mathrm{H}_{2} \mathrm{O}, 8.1 \mathrm{mg} / \mathrm{L} \mathrm{K}_{2} \mathrm{HPO}_{4}$, $0.0046 \mathrm{mg} / \mathrm{L} \mathrm{CuSO}_{4}, 0.023 \mathrm{mg} / \mathrm{L} \mathrm{ZnSO}_{4} 7 \mathrm{H}_{2} \mathrm{O}, 0.0119 \mathrm{mg} / \mathrm{L}$ $\mathrm{CoCl}_{2} 6 \mathrm{H}_{2} \mathrm{O}, 0.066 \mathrm{Na}_{2} \mathrm{MoO}_{4} 2 \mathrm{H}_{2} \mathrm{O}$ and $1.0 \mathrm{mg} / \mathrm{L} \mathrm{H}_{3} \mathrm{BO}_{3}$ ( $\mathrm{Hu}$ et al., 2018; Randall et al., 1984).

\subsection{Experimental procedure and analysis}

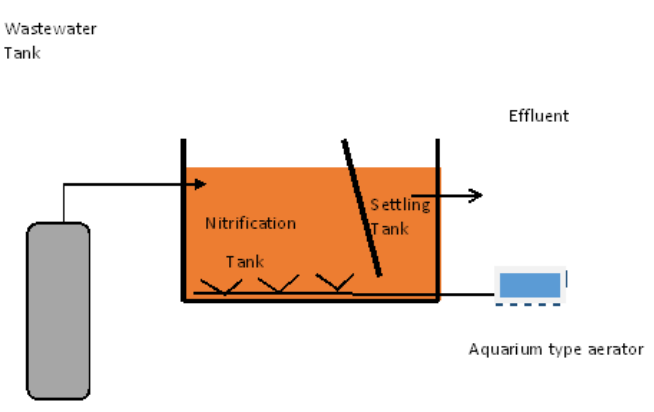

Figure 1. Laboratory Scale Experimental Setup

Before starting the experiments, the reactor was operated intermittently to create enough bacteria in the reactor. The sludge age was adjusted by removing sludge daily from the aeration tank. The experiments started after the system reached a steady state (E>90\%). In this study, the experiments were carried out primarily using OPE- and BPA-free synthetic wastewater. The experiments were studied at different hydraulic retention times $\left(\theta_{H}\right)$ and sludge ages $\left(\theta_{c}\right)$. The hydraulic retention time was changed in the range of 3-21 $\mathrm{h}$. The sludge age was adjusted between 4 and $30 \mathrm{~d}$. In the second series of experiments, the nitrification efficiency at different OPE and BPA concentrations (optimum hydraulic retention time and sludge age) was studied. The nitrification bacteria were obtained from the Lüleburgaz Domestic Wastewater Treatment Plant (from the nitrification section). The bacteria were reproduced in laboratory conditions under the optimum growth conditions and used in the experiments. Daily samples were taken from the reactor effluent and analyzed. The samples were centrifuged before analysis. Ammonium nitrogen (No: 1.14559.001, $\mathrm{NH}_{4}-\mathrm{N}=4-80 \mathrm{mg} / \mathrm{L}$ and $\mathrm{No}: 114752, \mathrm{NH}_{4}-\mathrm{N}=0.010-3.0$ $\mathrm{mg} / \mathrm{L}$ ), nitrate nitrogen (No: 1.14773.0001, $\mathrm{NO}_{3}-\mathrm{N}=0.2-20$ $\mathrm{mg} / \mathrm{L}$ ) and nitrite nitrogen (No: $114776, \mathrm{NO}_{2}-\mathrm{N}=0.002-1.00$ $\mathrm{mg} / \mathrm{L}$ ) measurements were made using Merck brand Spectroquant analytical kits. Dissolved oxygen concentration measurements were made with a Hanna DO analyzer. BPA (CAS No: 80-05-7; purity: 99.9\%) and OPE (Triton ${ }^{\text {TM }}$-X45; CAS 9002-93-1; purity: 98\%) were purchased from Sigma-Aldrich (USA) and Merck (Germany) and used without further purification. All reagents and solvents were 
of at least analytical grade and obtained from Merck (Germany), Fluka (USA) or Sigma-Aldrich (USA). The BPA and OPE analyses were carried out by using an HPLC device (Agilent 1100 Series, Agilent Technologies, USA) equipped with a diode array detector (G1315A, Agilent Series) and a Novapak C18 (3.9mm $\times 150 \mathrm{~mm}$, Waters, USA) reversed phase column (Dinçer et al., 2018).

\subsection{Kinetic equations}

Equation 1 is written based on the definition of the age of the sludge. In this equation, $\mu, \theta_{c}, Y$ and $b$ show the specific growth rate $\left(d^{-1}\right)$, sludge age $(d)$, growth efficiency coefficient (g. bacteria/g. Nitrogen) and death rate constant $\left(d^{-1}\right)$, respectively (Metcalf and Eddy, 2003).

$$
\mu=\frac{1}{\theta_{\mathrm{c}}}=\frac{Y \cdot N R_{\max } \cdot N}{K_{\mathrm{sat}}+N}-b=Y \cdot N R-b
$$

The nitrogen balance around the biological reactor tank results in the following equation. Here, NR is the specific nitrification rate ( $\mathrm{mgN} / \mathrm{mg} \mathrm{M} . \mathrm{d}), \mathrm{Q}$ is the flow rate $(\mathrm{L} / \mathrm{d}), \mathrm{V}$ is the biological reactor volume $(L), N_{o}$ and $N_{e}$ are the influent and effluent ammonium nitrogen concentrations $(\mathrm{mg} / \mathrm{L})$, respectively, $\mathrm{M}$ is the concentration of microorganisms present in the nitrification reactor $(\mathrm{mg} / \mathrm{L})$, $N R_{\text {max }}$ is the maximum nitrification removal rate $(1 / d)$, and $\mathrm{K}_{\text {sat }}$ is the saturation constant.

$$
\mathrm{NR}=\frac{Q\left(N_{\mathrm{o}}-N_{\mathrm{e}}\right)}{V \cdot M}=\frac{N R_{\text {max }} \cdot N}{K_{\text {sat }}+N}
$$

Equations 3 and 4 given below are used to express the effect of OPE and BPA on the nitrification rate (Dinçer et al., 1999). Here, NR shows the nitrification rate $(\mathrm{mgN} / \mathrm{mg}$ biomass.day), $N R_{\circ}$ is the nitrification rate without $A$ and OPE (1/day), KOPE and KBPA are the inhibition coefficients $(\mathrm{mg} / \mathrm{L})$, and OPE and BPA show the concentrations $(\mathrm{mg} / \mathrm{L})$.

$$
\begin{aligned}
& \mathrm{NR}=\frac{Q(\mathrm{No}-\mathrm{Ne})}{V \cdot M}=\mathrm{NR}_{\mathrm{o}} \frac{K_{\mathrm{OPE}}}{K_{\mathrm{OPE}}+\mathrm{OPE}} \\
& \mathrm{NR}=\mathrm{NR}_{\mathrm{o}} \frac{K_{\mathrm{BPA}}}{K_{\mathrm{BPA}+\mathrm{BPA}}}
\end{aligned}
$$

\section{Results and discussion}

\subsection{Nitrification kinetics of OPE- and BPA-free wastewater}

Nitrification kinetic constants were found from thdata obtained from the experiments at different hydraulic retention times (3-21 h) and sludge ages (4-30 d). Figure 2 shows the change in the nitrification rate depending on $1 / \theta_{c}$ in the nitrification system. The hydraulic retention time was fixed at $18 \mathrm{~h}$. Each experiment was performed for a week after the system reached a steady state. In the study conducted by Hocaoğlu et al. (2011), it was stated that nitrogen removal efficiency and kinetics changed significantly as a function of dissolved oxygen concentration and sludge age (Hocaoglu et al., 2011). From the definition of sludge age, the following mathematical equation may be written (Eq. 5). The $Y, N R_{\max }, K_{\text {sat }}$ and $b$ parameters were determined by using biological kinetic models. In Figure 2, the slope of the straight line is equal to $Y$, and the intercept is equal to $b$. In the mathematical equation, $\mu, \theta_{c}, Y$ and $b$ represent the specific growth rate $\left(d^{-1}\right)$, sludge age (d), growth yield coefficient (g.bacteria/g.nitrogen) and death rate constant $\left(\mathrm{d}^{-1}\right)$, respectively. Based on the experimental data, the relevant kinetic coefficients were found from Monod's equation (Metcalf and Eddy, 2003).

In Figure 2, the $Y$ value was found to be 0.296 , and the $b$ value was found to be 0.0337 .

$$
\mu=\frac{1}{\theta_{\mathrm{c}}}=\frac{Y \cdot N R_{\mathrm{max}} \cdot N}{K_{\mathrm{sat}}+N}-b=Y \cdot N R-b
$$

Therefore, when the coefficients are substituted in the equation, it takes the following form:

$$
\begin{aligned}
\mu & =\frac{1}{\theta_{c}}=\frac{Y . N R_{\max } \cdot N}{K_{\text {sat }}+N}-b \\
& =Y . N R-b=0.296 \times N R-0.0337
\end{aligned}
$$

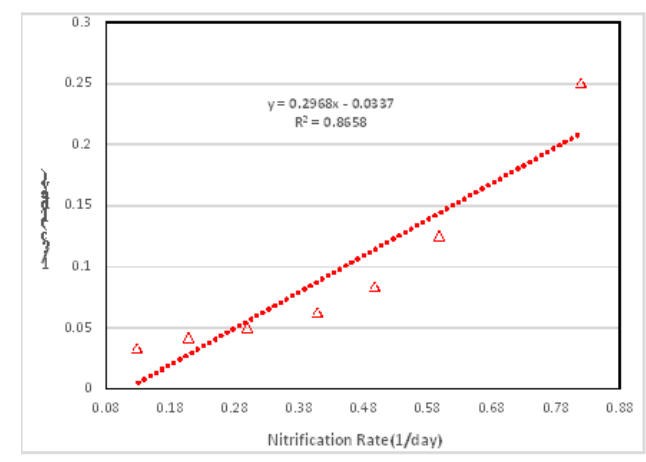

Figure 2. Determination of the growth yield coefficient and death rate constants for wastewater without OPE and BPA (a plot of $1 / \theta_{c}$ versus NR)

The nitrogen balance around the nitrification tank results in the following equation:

$$
\mathrm{NR}=\frac{Q\left(N_{\mathrm{o}}-N_{\mathrm{e}}\right)}{V \cdot M}=\frac{N R_{\max } \cdot N}{K_{\text {sat }}+N}
$$

In this equation, NR is the specific nitrification rate ( $\mathrm{mgN} / \mathrm{mg} \mathrm{M.d}), Q$ is the flow rate (L/d), $V$ is the nitrification tank volume (L), $N_{o}$ and $N_{e}$ are the influent and effluent ammonium nitrogen concentrations $(\mathrm{mg} / \mathrm{L}), \mathrm{M}$ is the bacteria concentration in the nitrification tank $(\mathrm{mg} / \mathrm{L})$, $N R_{\max }$ is the maximum nitrification rate $(1 / d)$, and $K_{\text {sat }}$ is the saturation constant.

The linearized form of Eq. 7 is:

$$
\frac{1}{\mathrm{NR}}=\frac{1}{\mathrm{NR}_{\max }}+\frac{K_{\text {sat }}}{\mathrm{NR}_{\max }} \times \frac{1}{N}
$$

The $N R_{\max }$ and $K_{\text {sat }}$ values were obtained from the $1 / N$ versus $1 /$ NR plot. The following values were found from the slope and intercept of the line $(y=4.4226 X+0.8796)$ : 


$$
N R_{\max }=1.14 \mathrm{~d}^{-1} \text { and } \mathrm{K}_{\text {sat }}=5.03 \mathrm{mg} / \mathrm{L}
$$

When all these values are replaced in Equation 1, the flowing equation is obtained in the wastewater without OPE (Figure 3). The kinetic coefficients found in this study were compatible with the current literature (Metcalf and Eddy, 2003).

$$
\mu=\frac{1}{\theta_{c}}=\frac{0.337 \times N}{5.03+N}-0.0337
$$

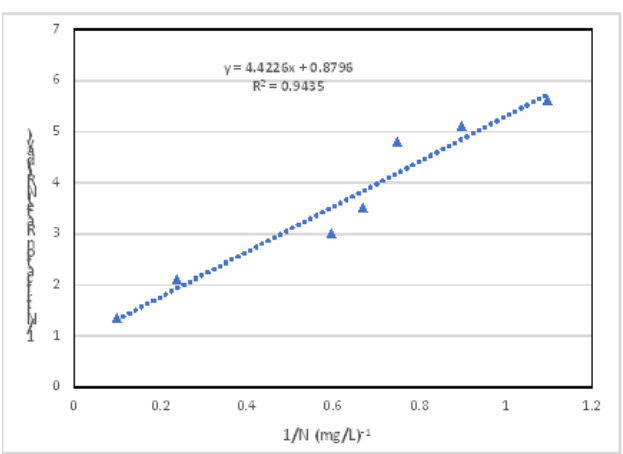

Figure 3. Determination of the $N R_{\max }$ and $\mathrm{K}_{\text {sat }}$ coefficients in wastewater without OPE and BPA (double reciprocal plot of $1 /$ NR versus $1 / N)$

\subsection{Effect of OPE and BPA on effluent $\mathrm{NH}_{4}-\mathrm{N}, \mathrm{NO}_{3}-\mathrm{N}$ and $\mathrm{NO}_{2}-\mathrm{N}$ concentrations}

Figure 4 shows the changes in the $\mathrm{NH}_{4}-\mathrm{N}, \mathrm{NO}_{3}-\mathrm{N}$ and $\mathrm{NO}_{2}-$ $\mathrm{N}$ concentrations depending on the OPE concentration. As the OPE concentration increased in the system, the $\mathrm{NH}_{4}-\mathrm{N}$ removal efficiency decreased. When the influent OPE concentration increased from $5.0 \mathrm{mg} / \mathrm{L}$ to 15 and $30 \mathrm{mg} / \mathrm{L}$, the effluent ammonium nitrogen concentration rose from $3.4 \mathrm{mg} / \mathrm{L}$ to respectively 7.5 and $20.4 \mathrm{mg} / \mathrm{L}$. The nitrate nitrogen concentration decreased by the increase in the OPE concentration. At the OPE concentrations of $5 \mathrm{mg} / \mathrm{L}, 15$ $\mathrm{mg} / \mathrm{L}$ and $30 \mathrm{mg} / \mathrm{L}$, the output $\mathrm{NO}_{3}-\mathrm{N}$ values were respectively $130.7 \mathrm{mg} / \mathrm{L}, 123 \mathrm{mg} / \mathrm{L}$ and $110 \mathrm{mg} / \mathrm{L}$. By the increase in the OPE concentration, nitrite accumulation was observed in the medium. The OPE concentration varied between 0.9 and $15.8 \mathrm{mg} / \mathrm{L}$. Depending on the OPE concentration, Nitrosomonas and Nitrobacter were negatively affected. The increased effluent ammonium concentration and nitrite accumulation in the medium showed that OPE induced an inhibition effect on Nitrosomonas and Nitrobacter.

Figure 5 shows the changes in $\mathrm{NH}_{4}-\mathrm{N}, \mathrm{NO}_{2}-\mathrm{N}$ and $\mathrm{NO}_{3}-\mathrm{N}$ depending on the BPA concentrations. Based on the increase in the BPA concentration in the medium, the effluent ammonium nitrogen and nitrite nitrogen concentrations increased. With the increased BPA concentration, the conversion of ammonium nitrogen into nitrate slowed down. At the BPA concentrations of $5 \mathrm{mg} / \mathrm{l}$, $10 \mathrm{mg} / \mathrm{L}, 15 \mathrm{mg} / \mathrm{L}, 20 \mathrm{mg} / \mathrm{L}, 25 \mathrm{mg} / \mathrm{L}$ and $30 \mathrm{mg} / \mathrm{L}$, the effluent ammonium concentrations were respectively 6.9 $\mathrm{mg} / \mathrm{L}, 10.3 \mathrm{mg} / \mathrm{L}, 15.4 \mathrm{mg} / \mathrm{L}, 26.8 \mathrm{mg} / \mathrm{L}, 35.9 \mathrm{mg} / \mathrm{L}$ and 49.8 $\mathrm{mg} / \mathrm{L}$. The effluent nitrite nitrogen concentration increased from $0.5 \mathrm{mg} / \mathrm{L}$ to $31.3 \mathrm{mg} / \mathrm{L}$. The conversion of ammonium nitrogen and nitrite nitrogen into nitrate nitrogen was negatively affected. At the BPA concentrations of $5.0 \mathrm{mg} / \mathrm{L}$, $15 \mathrm{mg} / \mathrm{L}$ and $30 \mathrm{mg} / \mathrm{L} \mathrm{BPA}$, the effluent nitrate nitrogen values were found respectively as $125.2 \mathrm{mg} / \mathrm{L}, 105.7 \mathrm{mg} / \mathrm{L}$ and $62.2 \mathrm{mg} / \mathrm{L}$. The increased BPA concentration created an inhibition effect on Nitrosomonas and Nitrobacter. The increase in ammonium nitrogen in the medium and nitrite nitrogen accumulation were an indicator of this. These endocrine disrupting compounds (OPE and BPA) showed a negative effect on the microorganisms in the nitrogen removal process. The inhibition effect of BPA on the nitrogen bacteria was found to be higher than that of OPE. Li et al. showed very low $\mathrm{NH}_{4}-\mathrm{N}$ oxidation at the highest PVC and $\mathrm{Cd}_{2}{ }^{+}$concentrations in their study. They found that ammonia oxidation was inhibited in the presence of PVC and $\mathrm{Cd}_{2}{ }^{+}$in the environment (Li et al., 2020).

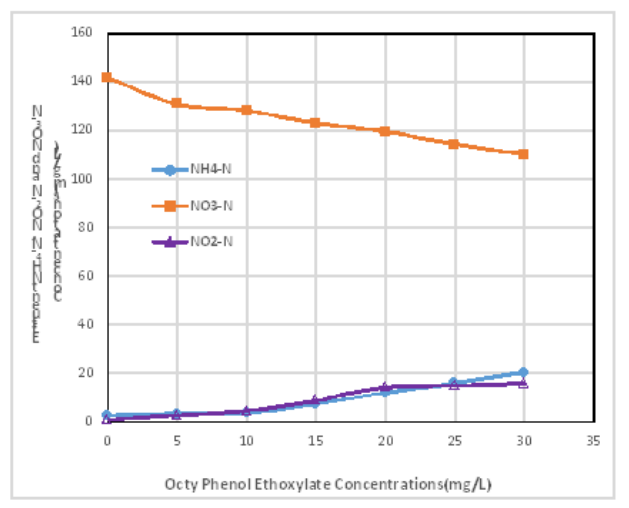

Figure 4. Effluent $\mathrm{NH}_{4}-\mathrm{N}, \mathrm{NO}_{3}-\mathrm{N}$ and $\mathrm{NO}_{2}-\mathrm{N}$ concentration change depending on the OPE concentration

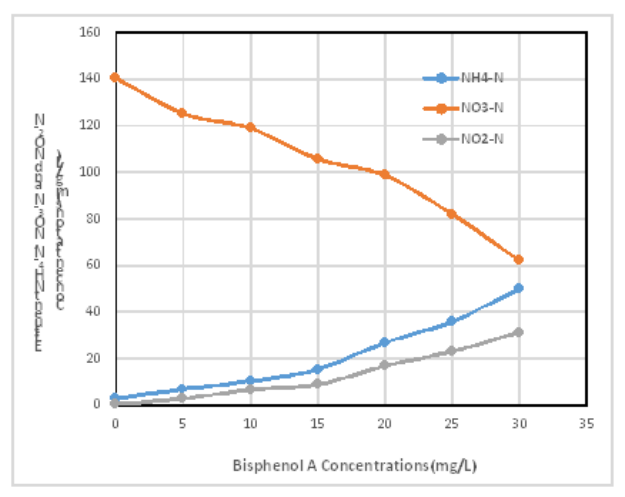

Figure 5. Effluent $\mathrm{NH}_{4}-\mathrm{N}, \mathrm{NO}_{3}-\mathrm{N}$ and $\mathrm{NO}_{2}-\mathrm{N}$ concentration change depending on the BPA concentration

\subsection{OPE and BPA inhibition kinetics of nitrification}

Figure 6 shows the change in the nitrification rate depending on the OPE and BPA concentrations. As the OPE concentration increased from 0 to $10 \mathrm{mg} / \mathrm{L}$ and $30 \mathrm{mg} / \mathrm{L}$, the nitrification rate decreased from $0.1008 \mathrm{~d}^{-1}$ to $0.1001 \mathrm{~d}^{-}$ ${ }^{1}$ and $0.088615 \mathrm{~d}^{-1}$, respectively. Likewise, as the BPA concentration increased from $5.0 \mathrm{mg} / \mathrm{L}$ to $30 \mathrm{mg} / \mathrm{L}$, the nitrification rate decreased from $0.0978 \mathrm{~d}^{-1}$ to $0.0685 \mathrm{~d}^{-1}$. The reaction rate slowed down even more at high BPA 
concentrations. In a study conducted on an activated sludge system in the current literature, when the BPA concentration was increased from $1.67 \mathrm{mg} / \mathrm{L}$ to $15 \mathrm{mg} / \mathrm{L}$, the loss of efficiency was found as $10 \%$. When OPE and BPA are present together, they create a more toxic effect on bacteria. Adsorption of BPA and OPE onto microorganisms takes place by a rate of $0.5 \%$ to $2 \%$ (Dinçer et al., 2018). BPA is found at low concentrations in receiving environments and has medium-level toxicity in organisms (Staples et al.,1998). When both curves are compared (Figure 6), it may be seen that BPA had a higher toxic effect than OPE. In the current literature, it has been reported that BPA cannot be removed by conventional biological treatment methods, because this compound is toxic, and it is not biodegradable (Rosenfeldt et al., 2004; Komesli et al., 2015). BPA is resistant to biological and chemical degradation (Akbari et al., 2016). In a nitrification study in a synthetic wastewater containing high ammonium nitrogen (200-400 $\left.\mathrm{mgNH}_{4}{ }^{+}-\mathrm{N} / \mathrm{L}\right)$, the kinetic constants for nitrogen removal following Monod's approach, the maximum substrate removal rate coefficient of 0.057 per day, half rate constant of $12.95 \mathrm{mg} \mathrm{NH}_{4}{ }^{+}-\mathrm{N} / \mathrm{L}$ and endogenous degradation constant of 0.02 per day were determined (Bhattacharya et al., 2020). In a study conducted by Dinçer et al., the maximum nitrification rate and saturation constant in salt-free wastewater were found to be 1.15 per day and $5.14 \mathrm{mg} / \mathrm{L}$, respectively. The maximum substrate removal rate and saturation constant at $3 \%$ salt concentration were $1 \mathrm{~d}^{-1}$ and $26 \mathrm{mg} / \mathrm{L}$, respectively (Dinçer et al., 2000).

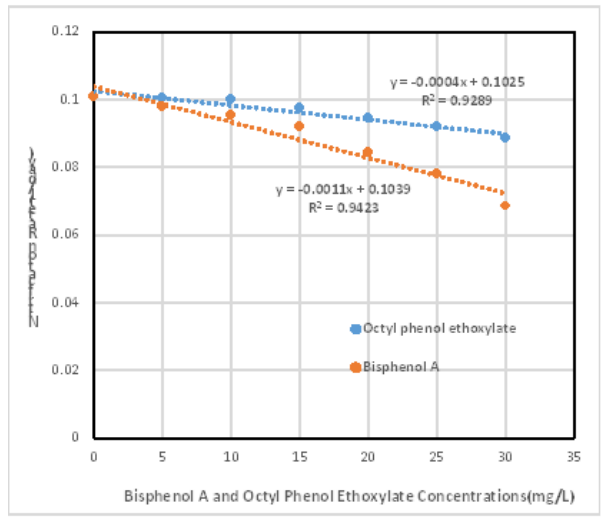

Figure 6. Variation of Nitrification rate with OPE and BPA concentrations

There is no mathematical model for inhibition of OPE and BPA on nitrification. Using the experimental data with different OPE and BPA concentrations, a plot of 1/NR against OPE and BPA were created as shown in Figure 7. The following rate equations were used to determine the inhibition constants of OPE and BPA (Dinçer et al., 1999; Dinçer et al., 2000).

$$
\mathrm{NR}=\frac{Q\left(N_{\mathrm{o}}-N_{\mathrm{e}}\right)}{V \cdot M}=\mathrm{NR}_{\mathrm{o}} \frac{K_{\mathrm{OPE}}}{K_{\mathrm{OPE}}+\mathrm{OPE}}
$$

$$
\mathrm{NR}=\mathrm{NR} \frac{K_{\mathrm{BPA}}}{K_{\mathrm{BPA}}+\mathrm{BPA}}
$$

Where Kope and KBPA are the OPE and BPA inhibition constants $(\mathrm{mg} / \mathrm{L}), \mathrm{OPE}$ and BPA are the OPE and BPA concentrations $(\mathrm{mg} / \mathrm{L}), \mathrm{NR}$ is the nitrification rate $(1 / \mathrm{d}), N R$ 。 is the OPE- and BPA-free nitrification $\operatorname{rat}(1 / d)$, and $M$ is the biomass concentration ( $\mathrm{mg} / \mathrm{L}$ ).

Eq. 10 and 11 are converted to the following form:

$$
\begin{aligned}
& \frac{1}{\mathrm{NR}}=\frac{1}{\mathrm{NR}_{\mathrm{o}}}+\frac{\mathrm{OPE}}{\mathrm{NR}_{\mathrm{o}}} \times \frac{1}{K_{\mathrm{OPE}}} \\
& \frac{1}{\mathrm{NR}}=\frac{1}{\mathrm{NR}_{\mathrm{o}}}+\frac{\mathrm{BPA}}{\mathrm{NR}_{\mathrm{o}}} \times \frac{1}{K_{\mathrm{BPA}}}
\end{aligned}
$$

Figure 7 shows the 1/NR values against the OPE and BPA concentrations. The following values were found from the slope and intercept of the line given in Figure 7. It was determined that the inhibition coefficient of BPA on the nitrification bacteria was 3.27 times more sensitive than OPE.

\section{$N R_{0}=0.103 d-1, K_{O P E}=207.8 \mathrm{mg} / \mathrm{L}$ and $\mathrm{NR}_{\mathrm{o}}=0.107$ $\mathrm{d}^{-1}, K_{\mathrm{BPA}}=63.58 \mathrm{mg} / \mathrm{L}$}

When the coefficients obtained from Figure 7 were replaced in Eq. 10 and 11, the following equations were obtained for nitrogen removal from wastewater containing OPE and BPA. Kinetic coefficients found based on experimental data may be used in the design of the nitrification process by using the following equations.

$$
\begin{aligned}
\mathrm{NR}_{\mathrm{OPE}} & =0.103 \times \frac{207.8}{207.8+\mathrm{OPE}} \text { and } \mathrm{NR}_{\mathrm{BPA}} \\
& =0.107 \times \frac{63.58}{63.58+\mathrm{BPA}}
\end{aligned}
$$

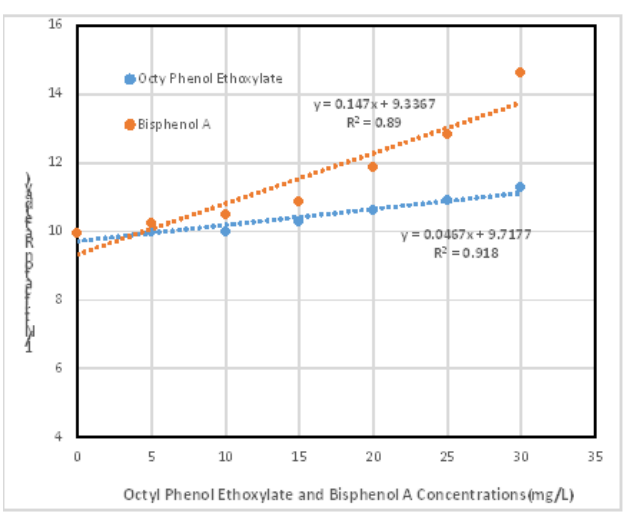

Figure 7. Variation of nitrification rate versus OPE and BPA concentration for determining the OPE and BPA inhibition constants

\section{Conclusions}

The yields of nitrification bacteria in a continuous flow reactor were investigated at different Octyl Phenol 
Ethoxylate (OPE) (0-30 mg/L) and Bisphenol A (BPA) (0-30 $\mathrm{mg} / \mathrm{L}$ ) concentrations. The ammonium removal rate decreased sharply at higher OPE and BPA concentrations. When the OPE and BPA concentrations were increased from $0 \mathrm{mg} / \mathrm{L}$ to $20 \mathrm{mg} / \mathrm{L}$ and $30 \mathrm{mg} / \mathrm{L}$, the nitrate nitrogen concentrations were found respectively as $141.5 \mathrm{mg} / \mathrm{L}$, $119.5 \mathrm{mg} / \mathrm{L}, 110.1 \mathrm{mg} / \mathrm{L}$ and $140.4 \mathrm{mg} / \mathrm{L}, 98.6 \mathrm{mg} / \mathrm{L}, 62.2$ $\mathrm{mg} / \mathrm{L}$. An increase in the concentrations of both compounds led to an accumulation of nitrite nitrogen in the medium. Additionally, due to the inhibition created by BPA and OPE on the Nitrosomonas bacteria, the effluent ammonium nitrogen concentration also increased. In nitrogen removal, BPA created a more toxic effect on the Nitrosomonas and Nitrobacter in comparison to OPE.

Based on the available data, the OPE and BPA inhibition constants, KOPE and KBPA, were determined to be $207.8 \mathrm{mg} / \mathrm{L}$ and $63.52 \mathrm{mg} / \mathrm{L}$, respectively. A kinetic model was developed in line with the available data.

\section{References}

Akbari S., Ghanbari F. and Moradi M. (2016), Bisphenol A degradation in aqueous solutions by electrogenerated ferrous ion activated ozone, hydrogen peroxide and persulfate: Applying low current density for oxidation mechanism, Chemical Engineering Journal, 294, 298-307.

Aslan Ş. (2017), Single and combined effects of copper and nickel on nitrification organisms in batch units, European Journal of Sustainable Development Research, 2(1), 51-56.

Auriol M., Filali-Meknassi Y., Tyagi R.D., Adams C.D. and Surampalli R.Y. (2006), Endocrine disrupting compoundsremoval from wastewater, a new challenge, ProcessBiochemistry, 41(3), 525-539.

Bhat S.A., Cui G., Li W., Wei Y. and Li F. (2020), Effect of heavy metals on the performance and bacterial profiles of activated sludge in a semi-continuous reactor, Chemosphere, 241, 125035.

Bhattacharya R. and Mazumder D. (2020), Kinetic study on nitrification of ammonium nitrogen enriched synthetic wastewater using activated sludge, Water Science and Technology, 81(1), 62-70.

Bolong N., Ismail A.F., Salim M.R. and Matsuura T. (2009), A review of the effects of emerging contaminants in wastewater and options for their removal, Desalination, 239(1-3), 229246.

Cirja M., Ivashechkin P., Schaffer A. and Corvini P.F. (2008), Factors affecting the removal of organic micropollutants from wastewater in conventional treatment plants (CTP) and membrane bioreactors (MBR), Reviews in Environmental Science and Bio/Technology,.7(1), 61-78.

Deborde M., Rabouan S., Mazellier P., Duguet J.P. and Legube B. (2008), Oxidation of bisphenol A by ozone in aqueous solution, Water Research, 42(16), 4299-4308.

Dinçer A.R., Güneş Y., Hancı T.Ö., Güneş E. and Khoei S. (2018), Effects of endocrine disrupting compounds (Bisphenol A and Octyl Phenol Ethoxylate) on COD removal efficiency. SAR Journal, 1(2), 35-41.

Dinçer A.R. and Kargı F. (2000), Kinetics of sequential nitrification and denitrification processes, Enzyme and Microbial Technology, 27(1-2), 37-42.
Dinçer A.R. and Kargı F. (1999), Salt inhibition of nitrification and denitrification in saline wastewater. Environmental Technology, 20,1147-1153.

Ferguson P.L., Iden C.R. and Brownawell B.J. (2000), Analysis of alkylphenol etoxylate metabolities in the aquatic environment using liquid chromatography electros pray mass spectrometry, Analytical Chemistry, 72(18), 4322-4330.

Hocaoglu S.M., Insel G., Çokgör E.U. and Orhon D. (2011), Effect of sludge age on simultaneous nitrification and denitrification in membrane bioreactor, Bioresource Technology, 102(12), 6665-6672.

Hu L., Zhang G., Liu M., Wang Q. and Wang P. (2018), Enhanced degradation of Bisphenol A (BPA) by peroxymonosulfate with $\mathrm{CO}_{3} \mathrm{O}_{4}-\mathrm{Bi}_{2} \mathrm{O}_{3}$ catalyst activation: Effects of $\mathrm{pH}$, inorganic anions, and water matrix, Chemical Engineering Journal, 338, 300-310.

Komesli O.T., Muz M., Ak M.S., Bakirdere S. and Gokcay C.F. (2015), Occurrence, fate andremoval of endocrine disrupting compounds (EDCs) in Turkish wastewater treatmentplants, Chemical Engineering Journal, 277, 202-208.

Lee Y.W., Ong S.K. and Sato C. (1997), Effects of Heavy Metals on Nitrifying Bacteria, Water Science and Technology, 36(12), 69-74.

Lee J., Lee B.C., Ra J.S., Cho J., Kim I.S., Chang N.I. and Kim S.D. (2008), Comparison of the removal efficiency of endocrine disrupting compounds in pilot scale sewage treatment processes, Chemosphere, 71(8), 1582-1592.

Llorca M., Badia-Fabregat M., Rodriguez-Mozaz S., Caminal G., Vicent T., and Barcelo D. (2017). Fungal treatment for the removal of endocrine disrupting compoundsfrom reverse osmosis concentrate: Identification and monitoring of transformationproducts of benzotriazoles, Chemosphere, 184, 1054-1070.

Li L., Li Z., Liu D. and Song K. (2020), Evaluation of partial nitrification efficiency as a response to cadmium concentration and microplastic polyvinylchloride abundance during landfill leachate treatment, Chemosphere, 247, 125903.

Metcalf and Eddy (2003), Wastewater Engineering: Treatment and Reuse, McGraw Hill, New York, NY, USA.

Nimrod A.C. and Benson W.H. (1996), Environmental estrogenic effects of Alkypenol ethoxylates, Criticial Reviews in Toxicology, 26(3), 335-364.

Peng Y.H., Chen Y.J., Chang Y.J. and Shih Y.S. (2015), Biodegradation of bisphenol A with diverse microorganisms from river sediment, Journal of Hazardous Materials, 286, 285-290.

Randall C.W. and Buth D. (1984), Nitrite build up in activated sludge resulting from temperature effects, Journal Water Pollution Control Federation, 56(9), 1039-1044.

Rosenfeldt E.J. and Linden K.G. (2004), Degradation of endocrine disrupting chemicals bisphenolA, ethinyl estradiol, and estradiol during UV photolysis and advancedoxidation processes, Environmental Science Technology, 20, 54765483.

Sharma V.K., Anquandah G.A., Yngard R.A., Kim H., Fekete J., Bouzek K. and Golovko D. (2009), Nonylphenol, octylphenol, and bisphenol $A$ in the aquatic environment: $A$ review on occurrence, fate, and treatment, Journal of Environmental Science and Health A, 44(5), 423-442. 
Spring A.J., Bagley D.M., Andrews R.C., Lemanik S. and Yang P. (2007), Removal of endocrine disrupting compounds using a membrane bioreactor and disinfection, Journal of Environmental Engineering and Science, 6(2), 131-137.

Staples C.A., Dorn P.B., Klecka G.M., Sondra T.O. and Harris L.R. (1998), A review of the environmental fate, effects, andexposures of bisphenol A., Chemosphere, 36(10), 21492173.

Umar M., Roddick F., Fan L. and Aziz H.A. (2013), Application of ozon efor the removal of bisphenol $A$ from water and wastewater A review, Chemosphere, 90(8), 2197-2207.

Urase T. and Miyashita K. (2003), Factors affecting the concentration of bisphenol $A$ in leachates from solid waste disposal sites and its fate in treatment processes, Journal of Material Cycles and Waste Management, 5(1), 77-82.

Yamamoto T., Yasuhara A., Shiraishi H. and Nakasugi O. (2001), Bisphenol $A$ in hazardous waste landfill leachates, Chemosphere, 42(4), 415-418.

Yeung C.H. and Francis C.A. (2013), Adaptation of nitrifying microbial biomass to Octyl Phenol Ethoxylate(OPE) in batch incubations, Applied Microbiology and Biotechnology, 97, 847-857.

Ying G.G., Kookana R.S., Kumar A. and Mortimer M. (2009), Occurrence and implications of estrogens and xenoestrogensin sewage effluents and receiving waters from South East Queensland, The Science of the Total Environment, 407(18), 5147-5155. 